\title{
Emended Circumscription of Begonia silletensis (Begoniaceae) and Description of a New Subspecies from Yunnan, China
}

\author{
Mark C. Tebbitt \\ Brooklyn Botanic Garden, 1000 Washington Avenue, Brooklyn, New York, \\ 11225-1099, U.S.A.
}

Guan Kaiyun

Kunming Institute of Botany, The Academy of Sciences of China, Kunming, Yunnan, China

Abstract. The circumscription of Casparya silletensis A. DC. ( = Begonia silhetensis (A. DC.) C. B. Clarke) is emended so as to accurately describe the type material of this species and exclude material of B. aborensis S. T. Dunn. Begonia silletensis subsp. mengyangensis, a taxon endemic to the Xishuangbanna region of Yunnan Province, China, is newly described and illustrated. Begonia silletensis subsp. mengyangensis differs from subspecies silletensis by its larger leaves (14-27 × 20-27 $\mathrm{cm}$ vs. $10-17 \times 10-15 \mathrm{~cm})$ and unequally ridged fruit. Begonia silletensis subsp. silletensis is reported new to Burma and Thailand. A key is provided to distinguish the two subspecies.

Key words: Begonia, Begoniaceae, China.

Approximately 70 species of Begonia L. are found in Yunnan Province, representing about 60\% of the total number found in China and 6 of the 18 Asiatic sections (Doorenbos et al., 1998). Begonia silletensis, a species previously considered restricted to northeastern India, was discovered in the Xishuangbanna region of Yunnan Province in 1977 during a Kunming Botanic Garden expedition and introduced into cultivation. Examination of the Begoniaceae collections of the Kunming Botanic Garden Herbarium has revealed additional material collected from the same region by an earlier SinoSoviet expedition in 1957. As these disjunct Chinese populations of $B$. silletensis differ from the northeast Indian populations by having larger leaves and unequally ridged fruit, the Chinese populations are recognized here as a new subspecies. Before we can compare the new subspecies with the typical B. silletensis, the description of B. silletensis requires emending.

De Candolle (1864) originally described Begonia silletensis as a species of the genus Casparya. The original circumscription of Casparya silletensis A. DC. does not match its type (Wallich 9107). De Candolle (1864) described C. silletensis as having velutinous petioles, peduncles, outer surfaces of the male perianth segments, and ovaries and hispidulous leaf blades. However, the type collection that he cited along with the description is glabrous throughout. Apart from this discrepancy, De Candolle's description of $C$. silletensis matches the type collection. We therefore suggest that De Candolle based his species on the Wallich 9107 collection and additional material of a different taxon. As no additional material is cited in his description of $C$. silletensis, the identity of this additional material is not certain. However, it is likely to have been $B$. aborensis $\mathrm{S}$. T. Dunn, as this species is covered with velvety hairs and is closely related to $B$. silletensis. Begonia aborensis was not recognized as a distinct species until 1920. In 1879, Clarke synonymized the genus Casparya with the genus Begonia and arbitrarily changed the spelling of the epithet "silletensis" to "silhetensis." Clarke (1879) certainly did include material of both $B$. silletensis and $B$. aborensis in his description of B. silhetensis. His circumscription of Begonia silhetensis $(=B$. silletensis) is based on Wallich 9107 and two other collections, Griffith 2569 and Wallich 3677B. Our research shows that Griffith 2569 and Wallich $3677 B$ are conspecific with Burkill's collections from the Abor Hills of northeastern India upon which Dunn (1920) based his Begonia aborensis. Clarke, in fact, suspected that his description was based on material of more than one species as he stated: "Griffith's No. 2569 (with which Wallich's No. 3677B agrees), differs considerably in hairiness and in size of the flower from Wallich's No. 9107 on which A.DC. founded his Casparya? silhetensis: two species are possibly here mixed, but the material is not sufficient to justify a new species" (Clarke, 1879: 636). The circumscription of Begonia silletensis is emended here so as to accurately describe the type (Wallich 9107) and exclude material that Dunn much later described as B. aborensis. Follow- 
ing Clarke (1879), the species is classified in the genus Begonia.

Begonia silletensis (A. DC.) C. B. Clarke emend. M. C. Tebbitt. Casparya silletensis A. DC., Prod. 15(1): 277. 1864. Begonia silhetensis (A. DC.) C. B. Clarke, in J. D. Hooker Fl. Brit. Ind. 2: 636. 1879. TYPE: Sillet Mts., Wallich 9107 (holotype, G-DC; isotypes, BM, KWALL).

\section{a. Begonia silletensis subsp. silletensis}

Dioecious perennial herbs. Stems prostrate, ca. 1 cm diam., internodes 1-2 cm, glabrous. Stipules persistent, lanceolate, $1.4-2.1 \times$ ca. $0.4 \mathrm{~cm}$, apex acute, margin entire, both surfaces glabrous. Leaves few, drooping; petioles 22-43 cm, glabrous; blade green, glabrous on both surfaces, ovate, 10-17 $\times$ $10-15 \mathrm{~cm}$, apex shortly acuminate, base asymmetric, sinus $3-4.5 \mathrm{~cm}$ deep, margin undulate, with short serrate teeth, primary veins $7-9$, palmate. Inflorescence axillary, an erect dichasium in which the primary peduncle branches vary from 0.1 to $5 \mathrm{~cm}$ so that the inflorescence is either umbellate or cymose in appearance, flowers fragrant, 1-10; peduncles $8-11 \mathrm{~cm}$ in both male and female inflorescences; bracts deciduous, ovate to elliptic, ca. 1.1 $\times 0.2 \mathrm{~cm}$, margin entire, both surfaces glabrous. Pedicels: those of male flowers $1-2 \mathrm{~cm}$, those of female flowers 4-5 cm. Male flowers: bracteoles absent; perianth segments white, greenish white or pink, 4, outer 2 ovate, oblong or obovate, concave, thick, $4.5-15 \times$ ca. $10 \mathrm{~mm}$, apex blunt, inner 2 ovate-obovate, $3.4-17.5 \times 7.5-8 \mathrm{~mm}$, apex rounded; stamens $100^{+}$, arranged in a symmetrical domeshaped mass, filaments $1.75-2.5 \mathrm{~mm}$, free to base, attached to a raised receptacle, anthers linear, 1.75-2.75 mm, dehiscing via vertical slits along side of anther, connective projecting $0.5 \mathrm{~mm}$, apex rounded. Female flowers: bracteoles absent, perianth segments white or pink, 4, oblong to obovate, apex rounded, outer 2 slightly longer; ovary ovoid to ellipsoidal, ca. $1 \times 1 \mathrm{~cm}$, circular in cross section, 4-locular, placentation axillary, placentae bifid, rhomboidal in cross section, ca. $4 \times 4 \mathrm{~mm}$, bearing ovules on both surfaces of branches; styles deciduous, 4 , very broad, base $0.5 \mathrm{~cm}$ across, $0.8-1.2$ $\mathrm{cm}$ long, fused just below half way, and then bifid, band of stigmatic papillae twice spirally twisted. Infructescences 1-2-fruited; fruiting pedicels ca. 3.5 $\mathrm{cm}$; fruit indehiscent, usually cork-like in texture or rarely leathery (in sicco), ovoid to ellipsoidal, 2.3 $\times 1.5 \mathrm{~cm}$, walls ca. $2.5 \mathrm{~mm}$ thick, lacking ridges or wings.
Northeastern India, Burma, and northern Thailand. We report it as new to Burma and Thailand. Wallich proposed the invalidly published name "Begonia gigantea" for this species based on the collection "Wallich 3677B" (Wallich, 1831).

Representative specimens. INDIA. Assam: Chanduar Forest, Mann 7/87 (K); Luckimpore, Makum $300 \mathrm{ft}$., 12.iv.1885, Clarke 37805 [specimen annotated by C. B. Clarke as "B. sphaerocarpa" nomen nudum] (K); Namchung, 155 ft., Luchimpore, 18.iv.1885, Clarke 37937A [specimen annotated by C. B. Clarke as "B. sphaerocarpa" nomen nudum] (K); Cachar, moist shade of Shapose Bomara, Nov. 1873, Keenan s.n. (K); Katakhal Forest, Mann s.n. (K). BURMA. Nammeen to Namma, Myitkina District, $1000 \mathrm{ft}$., 7.iii.1910, Lace 5170 (E). THAILAND. Northern Chiengmai, Trang, ca. $800 \mathrm{~m}$, 11.vi.1960, herb scattered in evergreen forest, by stream, fruits purplish red, angular, T. Smitinand \& H. St. John 6832 (K).

\section{b. Begonia silletensis subsp. mengyangensis $\mathrm{M}$.}

C. Tebbitt \& K.-Y. Guan, subsp. nov. TYPE: China. Yunnan: Xishuangbanna, on way from Puurem to Mengyang, bottom of valley in wet area in slope facing $\mathrm{N}$, dense forest, $21 \mathrm{Apr}$. 1957, Sino-Soviet Union expedition 9633 (holotype, KUN; isotype, KUN). Figure 1.

A B. silletensis subsp. silletensis foliis majoribus (ad 27 $\times 27 \mathrm{~cm}$ ); fructus globosus interdum carinatus.

Dioecious, perennial herbs, $20-50 \mathrm{~cm}$ tall. Stems prostrate, $1.5-4.0 \mathrm{~cm}$ diam., cortex red as seen in cross section, internodes $2-3 \mathrm{~cm}$, with sparse short hairs. Stipules persistent, reddish, not keeled, asymmetrically triangular-lanceolate, $2-2.5 \mathrm{~cm}$ long, dorsal surfaces with short hairs. Petioles green with white lenticels, red at base, 30-55 cm long, with short white hairs throughout; blades shiny green, leathery, glabrous above, paler green, hairy beneath, broadly ovate, $14-27 \times 20-27 \mathrm{~cm}$, apex acute, base cordate, slightly asymmetric, sinus 4.5 $11 \mathrm{~cm}$ deep, leaf bases overlapping, margin undulate, with short serrate teeth, primary veins 8 , palmate. Inflorescence axillary, an erect dichasium in which the primary peduncle branches are reduced to $1-3 \mathrm{~mm}$ long so that the inflorescence appears umbellate, flowers fragrant, ca. 15; peduncles: those of male inflorescence 10-15 cm long, with short white hairs, those of female inflorescence ca. $17 \mathrm{~cm}$ long, with short white hairs; bracts deciduous, narrowly to broadly ovate, $0.8-2 \times 0.2-1.2 \mathrm{~cm}$, both surfaces glabrous, margins shortly ciliate. Pedicels of male flowers 12-35 mm long. Male flowers: bracteoles absent; perianth segments white, sometimes flushed pink, 4 , outer 2 broadly ovate to broadly elliptic, ca. $15 \times 10-15 \mathrm{~mm}$, apex obtuse, outer surfaces pubescent, inner two broadly elliptic to broadly obovate, ca. $10 \times 12 \mathrm{~mm}$, apex obtuse, 




Figure 1. Begonia silletensis subsp. mengyangensis M. C. Tebbitt \& K.-Y. Guan. - A. Male plant. -B. Infructescence. -C. Fruit. - D. Transverse section of mature fruit. - E. Seed. - F. Male flower. —G. Female flower. Scale bars: A $=2.25 \mathrm{~cm} ; \mathrm{B}=2 \mathrm{~cm} ; \mathrm{C}, \mathrm{D}=1 \mathrm{~cm} ; \mathrm{E}=150 \mu \mathrm{m} ; \mathrm{F}, \mathrm{G}=2 \mathrm{~cm}$. 
outer surfaces glabrous. Stamens ca. 60, arranged in a symmetrical dome-shaped mass, filaments free to base, ca. $2 \mathrm{~mm}$ long, attached to a raised receptacle, ca. $1 \mathrm{~mm}$ high, anthers elliptic, ca. $2.2 \mathrm{~mm}$ long, dehiscing via vertical slits along side of anther, connective projecting $0.5 \mathrm{~mm}$, apex rounded. Pedicels of female flowers 1-2 cm long. Female flowers: bracteoles absent, perianth segments white, sometimes flushed pink, 4-6, outer $2-3$ ovate, ca. $15 \mathrm{~mm}$ long, apex obtuse, inner 2-3 elliptic to obovate, ca. $12 \mathrm{~mm}$ long, apex obtuse; ovary ellipsoidal, ca. $1 \times 1 \mathrm{~cm}$, 4-locular, placentation axillary, placentae bifid, bearing ovules on both surfaces of branches; styles long persisting but eventually deciduous, 4 , fused at base for 1.5-2 mm, bifid, band of stigmatic papillae once spirally twisted. Infructescence 4-6-fruited. Fruiting pedicels green, erect. to $3 \mathrm{~cm}$ long; fruit indehiscent, fleshy, ellipsoidal, (0.5-)1-2 cm diam., with short hairs, lacking ridges or wings or with up to 4 blunt unequal, triangular ridges (on same plant), ridges $2-3 \times 3-5 \mathrm{~mm}$ high. Seed ca. $300 \mu \mathrm{m}$ long.

Begonia silletensis subsp. mengyangensis grows among tall herbaceous vegetation in damp, shady areas in primary tropical forest at altitudes between 570 and $1200 \mathrm{~m}$; it has been collected with flowers and fruit in May and April. This taxon has proved amenable to cultivation, both at Kunming Botanic Garden, China, and Glasgow Botanic Gardens, Scotland.

Paratypes. CHINA. Yunnan: Xishuangbanna, Cheli liusha he, along riverside wet areas in shady forest, 600 800 m, 30 Apr. 1957, Sino-Soviet Union expedition 9834 (KUN); Xishuangbanna, Mengla, Mengyang, in valley under dense forest in wet areas, 1200 m, 5 Apr. 1957, Sino-
Soviet Union expedition 5869 (KUN-3 sheets); Mengla, Mengxin he, in valley, alt. $570 \mathrm{~m}, 19$ Mar. 1977, Xhangjianhou 13666 (KUN). CULTIVATED. Glasgow Botanic Garden National Begonia Collection, 18 Jan. 2000, L. L. Forrest 99 (E).

\section{Key to the Subspecies of BEGonIA SILLETENSIS}

1a. Leaves $10-17 \times 10-15 \mathrm{~cm}$; fruit lacking ridges $\ldots \ldots \ldots \ldots \ldots \ldots$ subsp. silletensis

1b. Leaves $14-27 \times 20-27 \mathrm{~cm}$; fruit unequally ridged . . . . . . . subsp. mengyangensis

Acknowledgments. We thank Adèle Rossetti Morosini who provided the illustration and Kerry Barringer, Laura Forrest, Katherine Gould, James Yeadon, and two anonymous reviewers who provided comments on the manuscript. We also thank David Chamberlain for helping to arrange the fieldwork and Ewan Donaldson and John Stevenson for providing cultivated material. This research was supported by the Biotechnology \& Biological Sciences Research Council (grant no. 93701311) and represents a portion of a Ph.D. dissertation submitted by the first author to the University of Glasgow, Scotland.

\section{Literature Cited}

Candolle, A. de. 1864. Begoniaceae. Prodr. 15: 266-408. Clarke, C. B. 1879. Begonia. P. 636 in C. B. Clarke (editor), Flora of British India, Vol. 2. L. Reeve, London.

Doorenboos, J., M. S. M. Sosef \& J. J. F. E. de Wilde. 1998. The sections of Begonia including descriptions, keys and species lists (Studies in Begoniaceae VI). Agric. Univ. Wageningen Pap. 98(2): 1-266.

Dunn, S. T. 1920. Plantarum Novarum in Herbario Horti Regii Conservatarum. Bull. Misc. Inform. 109-110.

Wallich, N. 1831. A Numerical List of Dried Specimens of Plants in the East India Company's Museum, Collected under the Superintendence of Dr. Wallich of the Company's Botanic Garden at Calcutta. P. 129. London. 


\section{$2 \mathrm{BHL}$ Biodiversity Heritage Library}

Tebbitt, Mark C. and Kaiyun, Guan. 2002. "Emended Circumscription of Begonia silletensis (Begoniaceae) and Description of a New Subspecies from Yunnan, China." Novon a journal of botanical nomenclature from the Missouri Botanical Garden 12, 133-136. https://doi.org/10.2307/3393252.

View This Item Online: https://www.biodiversitylibrary.org/item/14672

DOI: https://doi.org/10.2307/3393252

Permalink: https://www.biodiversitylibrary.org/partpdf/122117

\section{Holding Institution}

Missouri Botanical Garden, Peter H. Raven Library

\section{Sponsored by}

Missouri Botanical Garden

\section{Copyright \& Reuse}

Copyright Status: In copyright. Digitized with the permission of the rights holder.

License: http://creativecommons.org/licenses/by-nc-sa/3.0/

Rights: https://biodiversitylibrary.org/permissions

This document was created from content at the Biodiversity Heritage Library, the world's largest open access digital library for biodiversity literature and archives. Visit BHL at https://www.biodiversitylibrary.org. 